\title{
The Strategy to improve the Quality of Cashew Commodities
}

\author{
Ferdinan Demang, Salengke, Nurdin Brasit \\ Department of Agribusiness, Post Graduate School of Hasanuddin University, Perintis Kemerdekaan Street KM.10, \\ Makassar 90245, South Sulawesi, Indonesia
}

\begin{abstract}
One of the production centers of cashew nut is East Nusa Tenggara (NTT) province, during the period of 2011-2015 cashew nut production in this area continues to increase every year. Alor District is one of the cashewproducing regions in the province with total production reaching 2,000 tons. However, the resulting quality of production is considered poor. This research aims to formulate strategies to improve the quality of cashew nuts in alor district. This research was conducted in Pantar Tengah subdistric and West Pantar Subdistrict which can represent and describe the distribution of cashew nut production in Alor District in May to March 2017. Data analysis method used is SWOT to know the internal and external conditions which will then be used as a basis for designing work strategies and programs. The results showed that the main priority strategy for the development of cashew nut quality in Alor district is by forming a group of joint enterprises in the form of cooperatives owned by farmers.
\end{abstract}

Keywords-Strategy, Quality, Cashew.

\section{INTRODUCTION}

Cashew Commodities is one of the important plantation commodities to be developed because it is one of the country's foreign exchange earners. The value of cashew cashew nuts reached 78,825,562 \$ US in 2011 and then increased $17.34 \%$ in the following year to reach $95,362,347 \$$ US. The decline occurred 2 years in a row in 2013 and 2014 by $5.03 \%$ and $72.29 \%$ but again increased $71,42 \%$ to $184,395,079$ \$ US. This increase will continue to grow in line with the policy issued by the government that encourages the export of processed products. Industrial developments should be supported by an increase in the amount of production from both smallholders, state plantations and private plantations (Plantation Statistics of Indonesia, 2016).

The area of cashew plantation in Indonesia continues to show decline year by year. data on the total area in 2011 covering 575.841 ha and in 2015 to 522,863 ha. this is due to the number of people who convert the land to nonagricultural land. While the production from year to year is always increasing in 2011 as many as 114,789 tons increased in 2015 as much as 137,580 tons. increased production is influenced by the way of cultivation, maintenance and post-harvest cashew cashew in Indonesia which is good enough.

One of the central areas of cashew producers in Indonesia is the province of East Nusa Tenggara (NTT), during the period of 2011-2015 cashew nut production in this area continues to increase every year. The highest increase in production occurred in 2014, which increased by $10.69 \%$ from 39,360 to 44,072 Ton. Almost all districts and cities in this province have cashew nut production. in 2015 the highest production of cashew nut in East Flores district with total production reached 10,737 Ton, in the next sequence is Sikka district with total production 8,696 tons, next is Southwest Sumba District, east sumba and ende with total production respectively 5,035, 3,397 and 3,245 tons. In the sixth place is Alor district with total production reach 2000 tons (East Nusa Tenggara in Numbers, 2016).

Cashew production in Alor district fluctuates, in 2011 the total production reached 1,626 tons, then increased $20.37 \%$ in 2012 to 2,042 tons which was recorded as the highest increase during the period 2011-2015. In 2013 it decreased by $5.99 \%$ and then again increased in 2014 and 2015 by 0.51 and $2.98 \%$. Pantar Tengah Districts is the largest production area since 2011 until 2015 cashew nut production in this area has reached 400 tons more, the highest production occurred in 2012 which is 486 tons. Almost all sub-districts in Alor district produce cashew nuts, except Pura Island sub-district, this is due to geographical conditions that are not suitable for cashew cultivation. In cashew agribusiness, post-harvest stage plays a very important role in producing quality products (Alor in Numbers, 2016).

The development of cultivation and management of agricultural products for the welfare of the community is very necessary given that most of Alor's community depends on agriculture. In terms of the welfare of farmers need the intervention of local government in managing agricultural products and good supervision for the welfare of farmers can be felt. The sale of cashew plantation commodities has not guaranteed the welfare of farmers because the quality of cashew nuts produced is not so good to be marketed and the price is very low at the level 
of farmers. therefore it is necessary attention of local government and other related parties through the implementation of development programs, especially in the case of the development of cultivation and quality improvement of cashew komuditi products so as to improve the welfare of farmers and value-added cashew nuts products (Juran, 1995).

\section{METHOD}

\section{Location and Research Design}

This research was conducted in Pantar Tengah subdistric and West Pantar Subdistrict which can represent and describe the distribution of cashew nut production in Alor District in May to March 2017. To know the quality of cashew nuts in Alor District, the respondents consist of 10 respondents of collecting merchants, 5 respondents from large traders/inter island traders. Selection of respondents is done by considering that the respondent knows the condition and development and sales of cashew nuts in Alor District. Thus the total number of respondents is 105 respondents. This research aims to formulate strategies to improve the quality of cashew nuts in alor district.

The research method used is quantitative qualitative. while the type of data used is Primary data and secondary data. primary data consists of data obtained directly from the respondents ie farmers and traders who became the object in this study. Secondary data is data obtained from literature study and other data sources related to the research material

\section{METHOD OF COLLECTING DATA}

Data collection methods were conducted in this study include (1) Interview, that is by asking directly to the respondent. respondents in question are the farmers, traders and other parties associated with the development of cashew cashew in Alor District, (2) Recording, that is study by recording the necessary data both from respondents and related institutions that have supporting data in this research, (3) Observation, that is by doing direct observation to see the state of object in field and factors influencing performance of development and trade of cashew nuts in Alor District.

\section{DATA ANALYSIS}

Data analysis was done by using SWOT analysis and Analytical Hierarki Process (AHP). This analysis used to know is an internal and external conditions of an organization which will then be used as a basis for designing work strategies and programs. Internal analysis includes assesment of strength and weakness. Meanwhile, external analysis includes opportunity and challenge. There are two approaches in SWOT analysis that is qualitative and quantitative approach. Then the results of strategy analysis by using SWOT analysis is continued by www.ijeab.com using AHP method to know the main priority of the resulting strategy.

Data type in this research is primary and secondary data. Primary data is data obtained directly from respondents ie farmers and traders while secondary data is data obtained from literature studies and other data sources related to the research material.

\section{RESULT}

\section{Characteristics of Farmers Respondents}

Characteristics of respondents in this study include age, number of labor, education level, land area, production and income of cashew farmers. The average of respondents is $40-50$ years or $47.78 \%$ with variation ranging of 20-60 years old. the average amount of labor used by respondents is 1-3 people with $72.22 \%$ presentation, with range between 1-5 people. The education level of cashew farmers in Alor Regency is still low. The result showed that the average level of education of farmers is $54 \%$ of elementary school. this is due to lack of education infrastructure in the area. The area of cashew farmers in Alor District is $48.89 \%$ with an area of 1-2 Ha.T the average number of cashew nuts production of respondents in alor district is $50 \%$ of them get the production of $500 \mathrm{~kg}$ or 5 tons per responden. The selling price of cashew nuts ranged from Rp 11.000 - Rp 15.000 per kilogram. $92.22 \%$ of respondents sell their production at a price of 14.000-15.000 per kilogram. The result of cashew nut sales per responden reach five to ten million rupiah with percentage $47.78 \%$.

\section{Quality Standards of Cashew Commodities in Alor District}

In Indonesia, the quality standard of cashew nut is arranged in SNI 01-4463-1998 which divides cashew nut quality into 3 grade. whereas In Alor District cashew nut quality is only divided into 2 grade that is good and less good that can be interpreted by researcher into quality 2 and quality 3. Good cashew nut is not wrinkle, shiny skin and feels heavy. While the characteristics of cashew nutrient quality is less good is wrinkled skin, not shiny and deflated when pressed and feels lightly held. Cashew farmers in Alor District see cashew nut quality in a simple way called "lelesan". This method is considered as the best method because it can provide the best quality seeds.

\section{The Strategy to Improve The Quality Of Cashew Commodities}

a. Comparative Advantage Strategy

The strategy of comparative advantage is a meeting of two positive elements of strength and opportunity, in this condition the organization or company, or in this case the Alor district cashew agro industry can use the power to make the most of the opportunities available. One

Page | 15 
strategy that can be done is to form a group of joint ventures. By establishing a joint venture group, the strengths they have can be used to allow opportunities to get help from various stakeholders such as government support and technological developments can be better absorbed.

\section{b. Mobilization Strategy}

The essence of this strategy is how to direct the strengths (resources) that the organization has to mitigate the threats that can cause losses. One strategy that can be done is to carry out entrepreneurship training. The strategy is allegedly able to optimize resources owned by the organization to further improve efficiency, creativity and innovation

\section{c. Strategy Divestment / Investment}

This strategy is a meeting between the negative internal elements of weakness with the external positive element of opportunity. This strategy focuses on choosing between releasing good opportunities because the organization can not make good use (Divestment) or take advantage of the opportunities available to fix the weaknesses owned (Investment). One form of strategy is to form a Partnership business.

\section{d. Damage Control Strategy}

Meetings between threat elements and elements The weaknesses of an organization can be of great disadvantage if not well controlled. Organizational weaknesses such as the quality of unskilled human resources should be improved immediately. The ability to cultivate and post-harvest activities of good cashew nuts can protect the organization from any threat. Determination of strategy done qualitatively by the researcher by carefully analyzing the results of interviews, observations, references of previous research and direction of supervisor. Each Strategy is considered to be so important that it is necessary to determine which strategy will be a priority (Saragih, 2003).

The priority strategy is the earliest strategy to be implemented, the results showed that the strategy of ranks first is to form a Joint Business Group $(0,545)$, then establish a partnership business (0.228), carry out entrepreneurship training (0.12) and improve the Quality of Resources Man (0.107). Experts consider that the most appropriate strategy is the comparative advantage strategy of forming a group of joint ventures.

\section{DISCUSSION}

Most respondent farmers are of productive age where the average age of respondents is the ideal age for work and has the ability to increase work productivity, and has a great ability to absorb information but not innovative technology in agriculture. The level of education of farmers is still low which is just completing their education at the primary school. Education is one of the www.ijeab.com factors that determine the productivity of labor, in this case farmers. Farmers who have higher levels of education have a better ability to understand and apply Integrated Crop Management Technology of Cashew Commodities so that productivity becomes higher. (Luluk et al., 2008).

The quality of cashew nuts based on the Indonesian National Standard needs to be considered in trading the results of plantation commodities, especially the farmers of Alor District because it greatly affects the price of cashew nuts. the number of farmers who do not know the good quality at harvest make lower price on the farmer (Assauri, 1999) level. Several factors affect the level of knowledge are the level of education, the necessities of life, and the difficulty of accessing information. To get a high price at the farm level requires a new strategy to improve the quality of cashew nuts because the quality of cashew nuts can affect the price. by studying the National Standards of cashew nuts and applying them, then the resulting production will be of quality and the farmers will get a high price (Susanto, 2014).value chain is important to get more value than cashew seeds. the thing to do is to conduct postharvest management training that can produce processed products. the cashew nut business opportunity is still wide open due to the abundance of raw materials available in almost all parts of Indonesia (Permadi, 2006).

One of the things that can encourage the development of cashew business is to create a small cashew business group as a group forum to share knowledge and others so that problems encountered in the field can be completed together. Some of the advantages gained in the group, among them is the ease in finding capital and marketing, get coaching and agricultural extension. Through the group is expected to facilitate access to marketing and obtain credit from banks. An enterprise will be more optimal if run jointly, not only can minimize the capital used, the results of joint ventures are usually more profitable than the results of individual efforts. In addition, the knowledge of the work done will be more organized. Joint Business Group (KUB) is a container that collects and manages business together. the business groups get help from the government in the form of capital with the aim to improve the welfare of farmers (Haming, 2007).

\section{CONCLUSION AND RECOMMENDATION}

The target of cashew nut development in Alor District is to produce a quality product. The main priority strategy generated in this research is to form a joint business group in the form of koorporasi. This strategy is the best way for farmers to develop the quality of cashew nuts because it is a place to share experiences and get direct counseling training by the local government. There is a need for a

Page | 16 
feasibility study on the establishment of a Joint Business Group and a study on the value chain of cashew nut industry in Alor District to advance the cashew nut industry in the area.

\section{REFERENCES}

[1] Assauri. (1993). Production Management. Third Edition. Publisher: Faculty of Economics, University of Indonesia, Jakarta.

[2] Haming et al. (2007). Modern Production Management. Jakarta: Earth Literacy

[3] Juran. (1995). A history of Managing For Quality: The evolution, Trends, and Future Directions of Managing For Quality, ASQC Quality Press Milwaukee, WI.

[4] Luluk, et al. (2008) Management of Early Childhood Development Activities. Cet. 2nd.

[5] Plantation Statistics of Indonesia (2015). Central Bureau of Statistics.

[6] Permadi. (2006). Cashew nut crops. Depok: Spreading Self-Helpers.

[7] Susanto (2014). Review of Potential And Potential Superior Commodities

[8] Statistics Centre of East Nusa Tenggara. (2016). East Nusa Tenggara in Numbers.

[9] Saragih. (2003). Cashew Commodities. First Print. Ghalia Publisher Indonesia: Jakarta. 